\title{
YOGA HAMIL MENGGUNAKAN LANTUNAN ZIKIR BERPENGARUH TERHADAP PENURUNAN TEKANAN DARAH PADA IBU PREEKLAMSIA
}

\author{
Rosdiana $^{1}$, Lina Fitriani ${ }^{2}$ \\ ${ }^{1,2}$ STIKES Bina Generasi Polewali Mandar,Jl Mr Muh Yamin No.195 Manding,Polewali Mandar, \\ Sulawesi Barat,91315, Indonesia
}

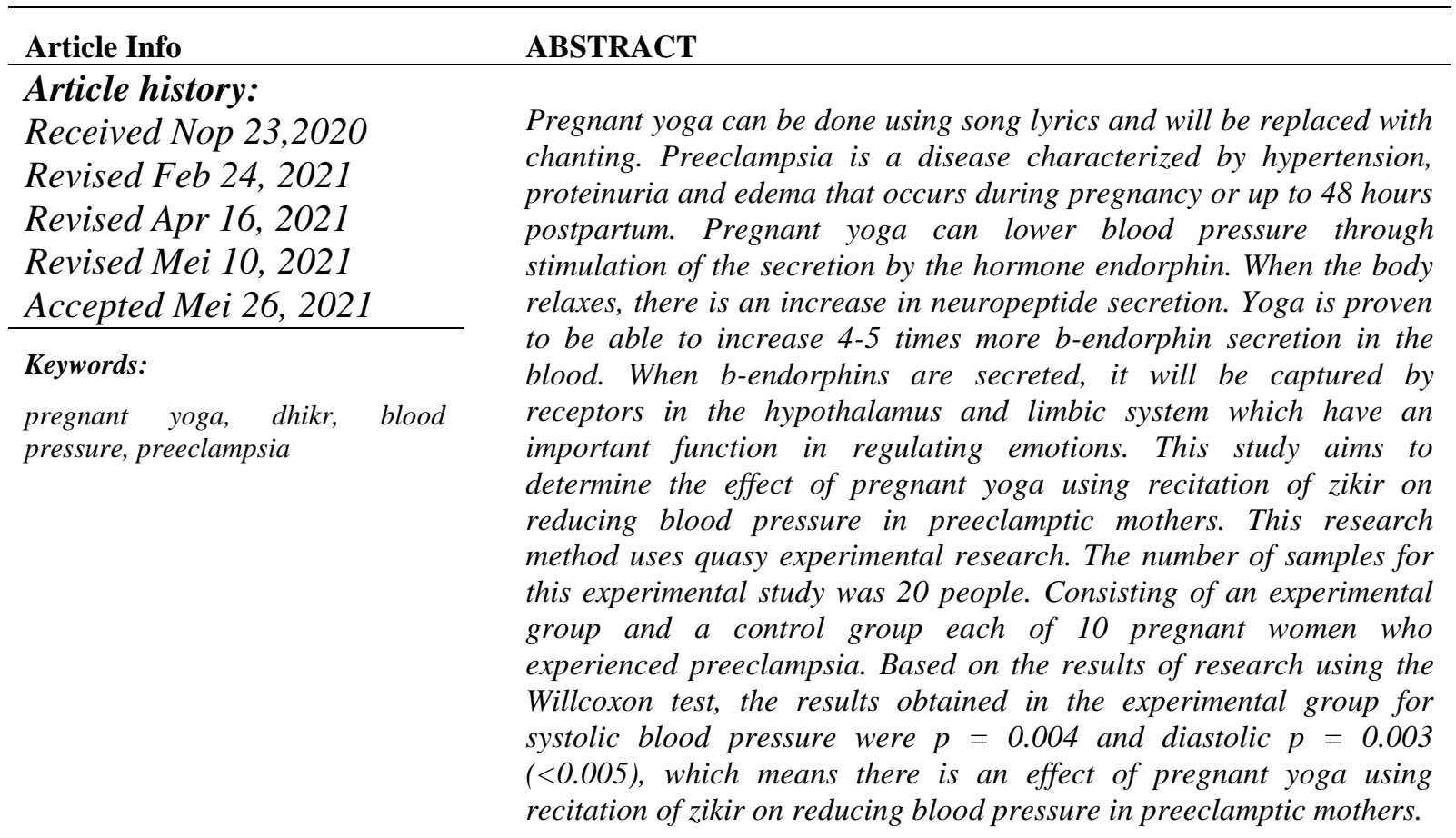

\section{Corresponding Author:}

Rosdiana ${ }^{1,}$ Lina Fitriani ${ }^{2}$

STIKES Bina Generasi Polewali Mandar, Fakultas Ilmu Keperawatan. Jl Mr Muh Yamin No 195

Manding,Polewali Mandar,Sulawesi Barat,91315, Indonesia

Email: rosdinarosdiana3@gmail.com, $\underline{\text { linafitriani@biges.ac.id }}$

\section{PENDAHULUAN}

Kehamilan dan persalinan adalah peristiwa alamiah yang dialami oleh seorang ibu, tetapi bagi ibu yang hamil anak pertama, hal ini sering dianggap sebagai peristiwa yang sangat mencemaskan. Bagi ibu hamil segala sesuatu yang berada disekitar hidupnya akan berpengaruh langsung pada dirinya. Oleh karena itu, banyak ibu hamil akan mengurangi pekerjaannya dengan cara mengurangi pekerjaan yang berhubungan dengan otot. 
Menurut Federasi Obstetri Ginekologi Internasional, kehamilan didefenisikan sebagai fertilisasi atau penyatuan dari spermatozoa dan ovum dan dilanjutkan dengan nidasi atau implantasi

Masa kehamilan dimulai dari konsepsi sampai lahirnya janin. Lamanya hamil normal adalah 280 hari (40 minggu atau 9 bulan 7 hari) dihitung dari hari pertama haid terakhir. Kehamilan dibagi dalam 3, triwulan pertama dimulai dari hasil konsepsi sampai 3 bulan, triwulan kedua dimulai dari bulan keempat sampai 6 bulan, triwulan ketiga dari bulan ketujuh sampai 9 bulan .

Menurut hasil penelitian menunjukkan bahwa ada penurunan tekanan darah pada ibu hamil primigavida sesudah melakukan jalan kaki sepuluh menit. Untuk menurunkan angka kematian ibu secara bermakna, kegiatan deteksi dini ibu hamil berisiko perlu lebih ditingkatkan baik di fasilitas pelayanan KIA maupun di masyarakat.

Yoga hamil merupakan bentuk pengobatan fisik dan spiritual yang sudah digunakan 5000 tahun yang lalu. Teknik yang digunakan pada saat yoga membawa keseimbangan pada aspek tubuh, pikiran dan kepribadian yang berbeda sehingga penggunaannya penuh dengan energi, kekuatan dan kejelasan tujuan hidup.

Prenatal yoga (yoga selama hamil) adalah salah satu jenis modifikasi dan hatha yoga yang disesuaikan dengan kondisi ibu hamil. Tujuan prenatal yoga adalah mempersiapkan ibu hamil secara fisik, mental dan spiritual untuk proses persalinan.

Yoga dalam kehamilan menggabungkan postur-postur khusus dan teknik-teknik yang bermanfaat bagi ibu hamil dan membantu menghilangkan ketidaknyamanan yang disebabkan oleh perubahan tubuh selama kehamilan. Yoga adalah sebuah ilmu yang menjelaskan kaitan antara fisik, mental, dan spiritual manusia untuk mencapai kesehatan yang menyeluruh.

Yoga hamil dapat menurunkan tekanan darah melalui stimulasi di sekresi oleh hormone endorphin pada saaat tubuh rileks maka terjadi peningkatan sekresi neuropeptide. Yoga terbukti mampu meningkatkan 4-5 kali lebih banyak sekresi bendorfin dalam darah saat b-endorfin di sekresikan maka akan ditangkap oleh reseptor dalam hipotalamus dan system limbic yang memiliki fungsi penting dalam mengatur emosi.

Yoga hamil dapat dilakukan dengan menggunakan lirik lagu dan akan diganti dengan lantunan zikir. Zikir adalah sebuah aktivitas ibadah dalam umat Muslim untuk mengingat Allah. Di antaranya dengan menyebut dan memuji nama Allah, dan zikir adalah satu kewajiban yang tercantum dalam al- Qur'an yang hampir $95 \%$ orang di Indonesia adalah beragama islam.

Allah telah memerintahkan kita untuk banyak berdzikir dan berdo'a didalam Al Qur'an dan hadist yang disampaikan Rasulullah. Sholat adalah salah satu kegiatan 
Dzikir \& Do'a yang diwajibkan bagi umat Islam. Diluar kegiatan sholat Allah juga memerintahkan agar kita memperbanyak dzikir dan do'a baik ketika berdiri , duduk dan berbaring dimanapun kita berada.

Kehamilan dan persalinan adalah peristiwa alamiah yang dialami oleh seorang ibu, terlebih bagi ibu yang hamil pertama. Salah satu penyulit dalam kehamilan yang bisa berdampak pada kematian maternal neonatal adalah preeklampsia. Hingga saat ini penyebab pasti dari preeklampsia belum diketahui, diduga usia dan paritas merupakan beberapa factor yang dapat mempengaruhinyaPreeklamsia adalah sebuah komplikasi pada kehamilan yang ditandai dengan tekanan darah tinggi (hipertensi) dan tanda-tanda kerusakan organ, misalnya kerusakan ginjal yang ditunjukkan oleh tingginya kadar protein pada urine (proteinuria).

Penurunan AKI terjadi di Sulawesi Barat sejak tahun 2006 sampai dengan 2017, yaitu dari 398 menjadi 176. Namun demikian, hasil laporan Program kesehatan Ibu tahun 2017 tidak menunjukkan penurunan kasus kematian ibu yang signifikan yaitu dari 47 kasus kematian ibu menjadi 39 kasus kematian. Angka kematian ibu dari kasus preeklamsia cukup banyak terjadi khusus nya di Kabupaten Polewali mandar dari 25 kematian ibu ditahun 2018 terdapat 50\% mengalami kasus preeeklamsia / hipertensi, selebihnya disebabkan penyebab tidak langsung kematian seperti TBC, jantung, Asma dll, 3 Terlambat dan 4 Terlalu. Jumlah Kematian Ibu di provinsi Sulawesi Barat tahun 2017 kabupaten Polewali Mandar menjadi kabupaten dengan Penyumbang terbesar Kematian Ibu yaitu 11 Kematian dan lebih meningkat tahun 2018 yaitu 25 kasus kematian.

Yoga merupakan bentuk pengobatan fisik dan spiritual yang sudah digunakan selama 5000 tahun yang lalu. Yoga berasal dari bahasa Sansekerta "yug" yang berarti "penyatuan" dan bermakna "penyatuan dengan alam" atau "penyatuan dengan sang pencipta". Teknik yang digunakan pada saat yoga membawa keseimbangan pada aspek tubuh, pikiran dan kepribadian yang berbeda sehingga penggunaannya penuh dengan energi, kekuatan dan kejelasan tujuan hidup. Yoga pada kehamilan memfokuskan kenyamanan serta keamanan dalam berlatih sehingga memberikan banyak manfaat Yoga selama hamil dapat meringankan edema dan kram yang sering terjadi pada bulan terakhir kehamilan, membantu posisi bayi dan pergerakkan, meningkatkan sistem pencernaan dan nafsu makan, meningkatkan energi dan memperlambat metabolisme untuk memulihkan ketenangan dan fokus, mengurangi rasa mual, morning sickness dan suasana hati, meredakan ketegangan di sekitar leher rahim dan jalan lahir yang berfokus pada membuka pintu pelvis untuk mempermudah persalinan, membantu dalam perawatan pasca kelahiran dengan mengembalikan uterus, perut dan dasar panggul, mengurangi ketegangan, cemas, dan depresi selama kehamilan maupun pada saat persalinan dan masa nifas, dan ketidaknyamanan pada payudara. 
Yoga yang dilakukan oleh ibu hamil secara teratur ternyata banyak manfaatnya bagi ibu dan janin. Di antaranya meningkatkan berat badan bayi saat dilahirkan, mengurangi terjadinya kelahiran prematur dan berbagai komplikasi kehamilan. Latihan yoga yang dilakukan diantaranya mencakup berbagai relaksasi, mengatur postur (yoga asanas), olah napas dan meditasi selama satu jam, rutin setiap hari. Hasilnya, 14\% kelompok rajin yoga yang melahirkan bayi prematur, sementara kelompok yang tidak beryoga $20 \%$. Selain itu kelompok beryoga juga lebih rendah tekanan darahnya. Hasil uji statistic didapatkan nilai $\mathrm{p}=0,005$ maka dapat disimpulkan ada perbedaan yang signifikan antara ke uhan ibu hamil sebelum dilakukan yoga antenatal dan setelah dilakukan yoga antenatal.

Prenatal gentle yoga adalah salah satu modifikasi hatha yoga yang disesuaikan dengan kondisi ibu hamil. Yoga ini dilakukan dengan intensitas lebih lembut, perlahan serta dengan memadukan gerakan yang menghubungkan pernafasan dan relaksasi sehingga ibu hamil merasa sehat, segar, nyaman, tenang, rileks, damai, dan bahagia serta siap menuju persalinan mudah, lembut (gentle birth), minim trauma dan fase pemulihan diri yang lebih cepat.

Manfaat Prenatal Gentle Yoga yaitu secara fisik, spiritual, dan mental. kontraindikasi prenatal gentle yoga yaitu Preeklampsi, Placenta praevia, Cervix incompetent, Tekanan darah > 120/80 mmH, Hipotensi (systole < $90 \mathrm{mmHg}$ ), Riwayat perdarahan dan keguguran pada kehamilan sebelumnya.

\section{Waktu tepat untuk kelas prenatalgentle yoga}

1. Mulai trimester 2 (minggu ke-14) kehamilan sehat dan normal, program bayi tabung minggu ke-20.

2. pagi pukul 00 atau 10.00 wib, sore pukul 15.00 atau 16.00 wib.

3. durasi 30-60 menit

4. seminggu 2-4 jadwal kelas.

5. tenang, dan damai.

Manfaat Prenatal Yoga: Fisik, Mental dan emosi, Spiritual Indikasi dan Kontraindikasi Yoga Hamil Pada prinsipnya yoga aman dilakukan oleh semua wanita hamil dan dapat dilakukan pada usia kehamilan 18 minggu, tidak memiliki riwayat komplikasi selama hamil, tidak memiliki riwayat persalinan preterm dan BBLR. Pada wanita dengan riwayat abortus boleh melakukan yoga setelah usia kehamilan lebih dari 20 minggu atau setelah dinyatakan kehamilan baik.

Kontraindikasi yoga hamil Walaupun yoga dianggap latihan yang aman namun terdapat beberapa keadaan dimana wanita memerlukan persetujuan dari tenaga kesehatan, seperti tekanan darah rendah, riwayat obstetrik buruk seperti perdarahan dalam kehamilan, KPD (ketuban pecah dini) dan BBLR. Selain keadaan tersebut yoga harus diberhentikan jika saat pelaksanaan ibu mengalami keluhan, seperti rasa pusing, mual dan muntah yang berkelanjutan, gangguan penglihatan, kram pada perut bagian 
bawah, pembengkakan pada tangan dan kaki, tremor pada ekstremitas atas maupun bawah, jantung berdebar-debar dan gerakkan janin melemah.

Zikir merupakan ibadah yang paling ringan, sekaligus paling besar kedudukannya dan paling utama di sisi-Nya. Hal ini dikarenakan gerak lidah adalah gerakan yang paling ringan dan paling mudah dari segenap anggota badan lainnya. Seandainya anggota badan lainnya bergerak sebanyak lidah bergerak (karena dzikir), niscaya ia akan letih, dan yang demikian itu tidak mungkin dilakukan. Macam-macam zikir: Dzikir dengan lidah (lisan), zikir dengan fikir, zikir dengan perasaan, zikir dengan keyakinan, Dzikir dengan perbuatan.

Sebagaimana fungsi dari zikir itu sendiri yang mana dzikir membuat orang yang membacanya menjadi tenang, maka dzikir pun memiliki banyak manfaat: Dzikir meninggikan derajat seseorang, Dzikir menyempurnakan pahala jihad, Dzikir menolak syaitan dan menghancurkannya, Dzikir membuat hati tenang Hilangnya duka cita dari hati Dzikir membuat Allah SWT. menjadi ridho Dzikir adalah cahaya bagi ahli dzikir baik di dunia, di alam kubur, dan di akhirat kelak

Dari sudut ilmu kesehatan jiwa, diketahui zikir merupakan terapi psikiatrik setingkat lebih tinggi daripada psikoterapi biasa. Zikir merupakan suatu upaya untuk mendekatkan diri kepada Allah dengan cara mengingat-Nya. Dalam Islam zikir bukanlah hal yang asing, tetapi sudah merupakan hal yang biasa dilakukan setiap muslim. Zikir di sini lebih berfungsi sebagai metode psikoterapi, karena dengan banyak melakukan zikir akan menjadikan hati tentram, tenang dan damai, serta tidak mudah diombang-ambingkan oleh pengaruh lingkungan dan budaya global. Seperti yang dikemukakan oleh Clinibel (Darokah \& Safaria, 2005) bahwa pada setiap individu terdapat kebutuhan dasar spiritual (basic spiritual needs) yang harus dipenuhinya. Seperti yang tercantum dalam surat Az-Zumar ayat 23 berikut: "Gemetar karenanya kulit orang-orang yang takut kepada Tuhannya. Kemudian menjadi tenang kulit dan dan hati mereka diwaktu mengingat Allah."

Beberapa perintah agar kita berdzikir dan berdo'a didalam Qur'an dan hadist antara lain sebagai berikut dibawah ini :

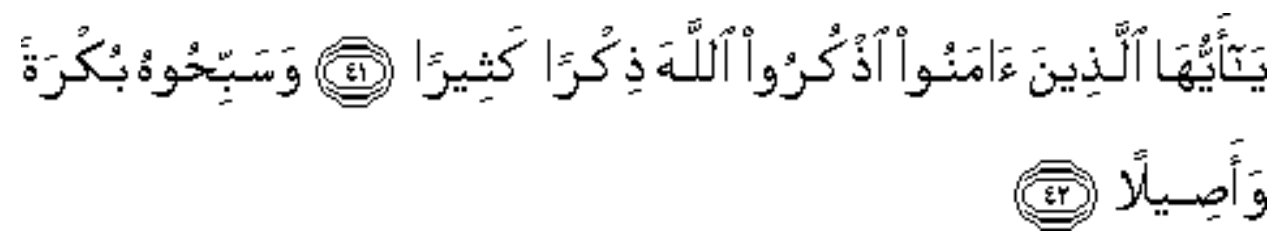




\section{Ayat ke 1:}

41- Hai orang-orang yang beriman, berzikirlah (dengan menyebut nama) Allah, zikir yang sebanyak-banyaknya. 42- Dan bertasbihlah kepada-Nya di waktu pagi dan petang. (Al Ahzab 41- 42)

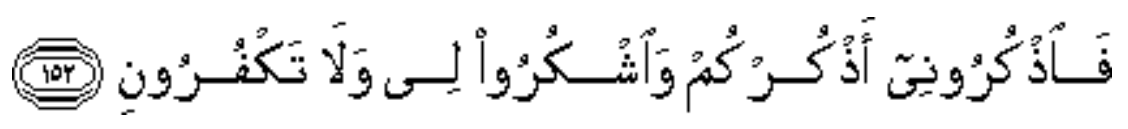

\section{Ayat ke 2}

152- Karena itu, ingatlah kamu kepada-Ku niscaya Aku ingat (pula) kepadamu, dan bersyukurlah kepada-Ku, dan janganlah kamu mengingkari (nikmat) -Ku. (Al Baqarah 152).

Preeklampsia adalah penyakit yang ditandai dengan adanya hipertensi, proteinuria dan edema yang timbul selama kehamilan atau sampai 48 jam postpartum. Umumnya terjadi pada trimester III kehamilan. Preeklampsia dikenal juga dengan sebutan Pregnancy Incduced Hipertension (PIH) gestosis atau toksemia kehamilan.Penyebab timbulnya preeklampsia pada ibu hamil belum diketahui secara pasti, tetapi pada umum nya disebabkan oleh (vasospasme arteriola). Faktor-faktor lain yang diperkirakan akan mempengaruhi timbulnya preeklampsia antara lain: primigravida, kehamilan ganda, hidramnion, molahidatidosa, multigravida, malnutrisi berat, usia ibu kurang dari 18 tahun atau lebih dari 35 tahun serta anemia. Preeklampsia dibagi dalam golongan ringan dan berat tanda / gejala: Hipertensi dengan tekanan darah 160/110 $\mathrm{mmHg}$ atau lebih, diukur minimal 2 kali dengan jarak waktu 6 jam pada keadaan istirahat.Proteinuria 5 gram/ 24 jam atau lebih, +++ atau ++++ pada pemeriksaan kualitatif.Oliguria, urine $400 \mathrm{ml} / 24$ jam atau kurang Edema paru-paru, sianosis, Pertumbuhan janin intrauterine terlambat,

Adanya HELLP syndrome $(H=$ Hemolysis, ELL= Elevated Liver Enzym, $P=$ Low Plat.Pencegahan timbulnya preeklampsia dapat dilakukan dengan pemeriksaan antenatal care secara teratur. Gejala yang ditangani secara tepat. Penyuluhan tentang manfaat isirahat akan banyak berguna dalam pencegahan. Istirahat tidak selalu berarti tirah baring di tempat tidur, tetapi ibu masih dapat melakukan kegiatan sehari-hari, hanya dikurangi antara kegiatan tersebut, ibu dianjurkan duduk atau berbaring. Nutrisi penting untuk diperhatikan selama hamil, terutama protein. Diet protein yang adekuat bermanfaat untuk pertumbuhan dan perbaikan sel dan transformasi lipid. 


\section{METODE PENELITIAN}

Metode penelitian ini menggunakan penelitian Pra Eksperimen (Pra-Experiment Desaign). Sampel menggunakan kelompok eksperimen tanpa kelompok kontrol, maka jumlah anggota sampel adalah 10 sample ibu hamil yang mengalami preeklamsia. Tehnik pengambilan sample menggunakan Purposive sampling. sample penelitian akan di buat menjadi 1 kelompok (one group) pretest dan post test design. pada sample penelitian akan dilakukan pemeriksaan tekanan darah sebelum dilakukan yoga hamil dan setelah dilakukan yoga hamil untuk melihat perbedaan setelah pemberian terapi. Yoga dilakukan sebanyak tiga kali dengan durasi 30-60 menit selama 1 minggu kepada setiap ibu hamil. Uji statistik Pre eksperimen menggunakan Analisis bivariat yaitu akan diolah melalui program sofhware SPSS dengan menggunakan uji Paired $T$ Test termasuk uji statistic non parametrik. Uji ini dilakukan untuk tes dua sampel yang saling berhubungan. Penggunaan uji ini untuk melihat apakah ada perbedaan atau perubahan antara 2 peristiwa sebelum dan sesudahnya pemberian terapi.

\section{HASIL DAN PEMBAHASAN}

Tabel 1 Hasil Uji Statistik Wilcoxon untuk Kelompok Eksperimen dan Kelompok Kontrol

\begin{tabular}{|c|c|c|c|}
\hline \multirow[t]{2}{*}{ No. } & \multirow[t]{2}{*}{ Variable/ Kelompok } & Median & \multirow[t]{2}{*}{$\mathbf{P}$} \\
\hline & & Min/Max & \\
\hline \multirow[t]{5}{*}{1} & EKSPERIMEN & & \\
\hline & Sistolik Sebelum & $140,00(130 / 160)$ & \multirow[t]{2}{*}{0,004} \\
\hline & Sistolik Sesudah & $120,00(110 / 140)$ & \\
\hline & Diastolik Sebelum & $100,00(90 / 100)$ & \multirow[t]{2}{*}{0,003} \\
\hline & Diastolik Sesudah & $80,00(70 / 90)$ & \\
\hline \multirow[t]{5}{*}{2} & KONTROL & & \\
\hline & Sistolik Sebelum & $135,00(130 / 150)$ & \multirow[t]{2}{*}{0,083} \\
\hline & Sistolik Sesudah & $135,00(120 / 140)$ & \\
\hline & Diastolik Sebelum & $90,00(90 / 100)$ & \multirow[t]{2}{*}{0,025} \\
\hline & Diastolik Sesudah & $90,00(80 / 90)$ & \\
\hline
\end{tabular}

Berdasarkan tabel di atas dapat dilihat bahwa dengan menggunakan uji willcoxon pada kelompok eksperimen nilai $\mathrm{p}$ untuk TD sistolik 0,004 dan diastolik $\mathrm{p}=0,003$ $(<0,005)$. Sedangkan pada kelompok kontrol nilai $\mathrm{p}$ untuk TD darah sistolik adalah $\mathrm{p}=$ 0,083 dan TD diastolik adalah $\mathrm{p}=0,025$.

Dari hasil tersebut menunjukkan bahwa kelompok eksperimen menunjukkan bahwa terdapat pengaruh yang signifikan terhadap perubahan tekanan darah sebelum dan sesudah 
dilakukan intervensi dengan nilai $\mathrm{p}<0,005$ (Ho ditolak dan Ha diterima), maka pada kelompok kontrol dapat menyimpulkan bahwa tidak ada pengaruh pada pengurangan tekanan. darah dengan nilai p> 0,005 (Ho diterima dan Ha ditolak).

Dari hasil tersebut menunjukkan bahwa kelompok eksperimen menunjukkan bahwa terdapat pengaruh yang signifikan terhadap perubahan tekanan darah sebelum dan sesudah dilakukan intervensi dengan nilai $\mathrm{p}<0,005$ (Ho ditolak dan Ha diterima).

Menurut hasil penelitian menunjukkan bahwa ada penurunan tekanan darah pada ibu hamil primigavida sesudah melakukan jalan kaki sepuluh menit. Untuk menurunkan angka kematian ibu secara bermakna, kegiatan deteksi dini ibu hamil berisiko perlu lebih ditingkatkan baik di fasilitas pelayanan KIA maupun di masyarakat.

Yoga merupakan bentuk pengobatan fisik dan spiritual yang sudah digunakan selama 5000 tahun yang lalu. Yoga berasal dari bahasa Sansekerta "yug" yang berarti "penyatuan" dan bermakna "penyatuan dengan alam" atau "penyatuan dengan sang pencipta". Teknik yang digunakan pada saat yoga membawa keseimbangan pada aspek tubuh, pikiran dan kepribadian yang berbeda sehingga penggunaannya penuh dengan energi, kekuatan dan kejelasan tujuan hidup.

Prenatal yoga yang dilakukan menekan kinerja dari sistem saraf simpatissehinggaakan terjadi hambatan stimulus medula adrenal untuk mengeluarkan katekolamin (epinefrin dan norepinefrin). Penurunan katekolamin menyebabkan vasodilatasi pembuluh darah ginjal dan hampir seluruh organ viseral sehingga terjadi penurunan tekanan darah dan memperlancar distribusi darah setiap menit. Pada penelitian yang dilakukan di India, Yoga dapat menurunkan tekanan darah dan mengurangi level stres oksidatif .

Prenatal yoga merupakan salah satu latihan fisik yang aman untuk ibu hamil.Penurunan tekanan darah sistol terjadi karena prenatal yoga bisa melancarkan aliran darah, melancarkan suplai oksigen dan nutrisi serta memperkuat otot pernafasan dan jantung. Latihan pernafasan pada yoga mengoptimalisasikan kapasitas paru dan latihan postur menguntungkan bagi meningkatnya kemampuan otot jantung.

Pada penelitian yang dilakukan oleh Hamdiah pada tahun 2017, yoga tidak signifikan mempengaruhi tekanan darah diastol. Penurunan tekanan darah diastolik dipengaruhi oleh peningkatan elastisitas pembuluh darah arteri yang berhubungan dengan penurunan resistensi pembuluh perifer.

\section{KESIMPULAN}

Hasil yang diperoleh pada kelompok eksperimen untuk tekanan darah sistolik adalah $\mathrm{p}=0,004$ dan diastolik $\mathrm{p}=0,003(<0,005)$ yang berarti Ada pengaruh yoga hamil menggunakan lantunan zikir terhadap penurunan tekanan darah pada ibu preeklamsia. 


\section{UCAPAN TERIMA KASIH}

Mengucapkan terimakasih kepada Kepala Puskesmas Pekkabata Kabupaten Polewali Mandar, para Staf dan Kader Puskesmas Pekkabata yang terlibat pada penelitian serta pihak lain yang ikut terlibat dalam penelitian

\section{DAFTAR RUJUKAN}

1. Ariyanti, 2020. Prenatal Gentle Yoga, Griya Cantik Esther.

2. Devi, dkk., Pengaruh Yoga Antenatal Terhadap Pengurangan Keluhan Ibu Hamil Trimester III. jurnal kedokteran dan kesehatan, volume 1, no. 1, oktober 2014

3. Islamic \& Titik., Prenatal Yoga dan kondisi kesehatan ibu hamil . jurnal Ilmu Kebidanan dan kebidanan. Volume 10 No. 1. 2019

4. Laporan Tahunan Pengurus Cabang Ikatan Bidan Indonesia Kab. Polewali Mandar, "Pengurus Cabang Ikatan Bidan Indonesia Kab.Polewali Mandar,"Ikatan Bidan Indonesia Polewali Mandar, Indonesia,2019

5. Latifin, Khoirul dan Satria Yudha Kusuma. 2014. Panduan Dasar Klinik Keperawatan. Malang: Penerbit Gunung Samudera.

6. Lockhart, Anita dan Lyndon Saputra. 2014. Asuhan Kebidanan Kehamilan Fisiologis \& Patologis. Tangerang Selatan: Binarupa Aksara.

7. Maryam, Siti. 2016. Perbedaan Senam Hamil dan Yoga Hamil Terhadap Kecemasan Menghadapi Persalinan. Tesis: Universitas Sebelas Maret Surakarta.

8. Mufdlilah. 2009. Panduan Asuhan Kebidanan Ibu Hamil. Jogjakarta: Nuha Medika.

9. Maryam, Siti. 2016. Perbedaan Senam Hamil dan Yoga Hamil Terhadap Kecemasan Menghadapi Persalinan. Tesis: Universitas Sebelas Maret Surakarta.

10. Nurfadila, 2011, Perintah Dzikir dan Do'a Dalam Qur'an dan Hadist, Jakarta, Pondok Tadabbur

11. Pratignyo, T. 2014. Yoga Ibu Hamil plus Postnatal Yoga. Jakarta: Pustaka Bunda

12. Prawirohardjo, Sarwono. 2014. Ilmu Kebidanan. Jakarta: PT Bina Pustaka Sarwono Prawirohardjo.

13. Pengurus Cabang Ikatan Bidan Indonesia Kab. Polewali Mandar. 2019. Kabupaten Polewali Mandar.

14. Rafika, 2018 Efektivitas Prenatal Yoga terhadap Pengurangan Keluhan Fisik pada Ibu Hamil Trimester III. Jurnal Kesehatan Volume 9, Nomor 1, April 2018

15. Rodiani, dkk. 2019. Hubungan antara Prenatal Yoga dengan Tekanan Darah Pasien Hipertensi dalam Kehamilan pada Kelompok Prenatal Yoga Klinik Krakatau. Fakultas Kedokteran Universitas Lampung. 
e-ISSN: 2541-4542

16. Sindhu, Pujiastuti. Yoga untuk Kehamilan: Sehat, Bahagia dan Penuh Makna.Bandung: Mizan Digital Publishing

17. Sofian, Amru. 2011. Rustam Mochtar Sinopsis Obstetri: Obstetri Operatif, Obstetri Sosial. Jakarta: EGC.

18. Widuri, ", pengaruh terapi relaksasi zikir untuk menurunkan stres pada penderita hipertensi esensial," Intervensi Psikologi, vol. 6, no. 1, pp. 1-7, Juni 2014. 